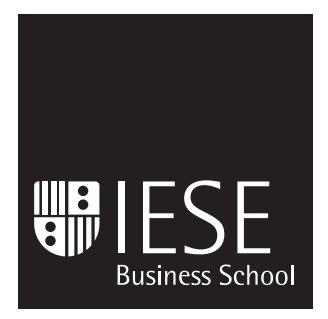

Working Paper

WP-757

CIIF

July, 2008

University of Navarra

\title{
THE EQUITY PREMIUM IN 100 TEXTBOOKS
}

\author{
Pablo Fernández
}

Av. Pearson, 21 - 08034 Barcelona, Spain. Phone: (+34) 932534200 Fax: (+34) 932534343

Camino del Cerro del Águila, 3 (Ctra. de Castilla, km 5,180) - 28023 Madrid, Spain. Phone: (+34) 913570809 Fax: (+34) 913572913

Copyright ${ }^{\odot} 2008$ IESE Business School. 
The CIIF, International Center for Financial Research, is an interdisciplinary center with an international outlook and a focus on teaching and research in finance. It was created at the beginning of 1992 to channel the financial research interests of a multidisciplinary group of professors at IESE Business School and has established itself as a nucleus of study within the School's activities.

Ten years on, our chief objectives remain the same:

- Find answers to the questions that confront the owners and managers of finance companies and the financial directors of all kinds of companies in the performance of their duties

- Develop new tools for financial management

- Study in depth the changes that occur in the market and their effects on the financial dimension of business activity

All of these activities are programmed and carried out with the support of our sponsoring companies. Apart from providing vital financial assistance, our sponsors also help to define the Center's research projects, ensuring their practical relevance.

The companies in question, to which we reiterate our thanks, are:

Aena, A.T. Kearney, Caja Madrid, Fundación Ramón Areces, Grupo Endesa, Royal Bank of Scotland and Unión Fenosa.

http://www.iese.edu/ciif/ 


\title{
THE EQUITY PREMIUM IN 100 TEXTBOOKS
}

\author{
Pablo Fernández ${ }^{1}$
}

\section{Abstract}

I revise 100 finance and valuation textbooks published between 1979 and 2008 by authors such as Brealey and Myers, Copeland, Damodaran, Merton, Ross, Bruner, Bodie, Penman, Weston, Brigham and Arzac and find that their recommendations regarding the equity premium range from $3 \%$ to $10 \%$. I also find that several books use different equity premia on different pages.

Some of the confusion arises from not distinguishing among the four concepts that the term equity premium designates: historical equity premium, expected equity premium, required equity premium and implied equity premium.

Finance textbooks should clarify the equity premium by providing distinguishing definitions of these four concepts and conveying a clearer message about their sensible magnitudes.

${ }^{1}$ Professor, Financial Management, PricewaterhouseCoopers Chair of Finance, IESE

JEL Classification: G12, G31, G32

Keywords: equity premium; equity premium puzzle; required market risk premium; historical market risk premium; expected market risk premium; risk premium; market risk premium; market premium. 


\section{THE EQUITY PREMIUM IN 100 TEXTBOOKS}

\section{Introduction}

The equity premium (also called market risk premium, equity risk premium, market premium and risk premium) is one of the most important and most discussed but also most elusive parameters in finance. Part of the confusion arises from the fact that the term equity premium is used to designate four different concepts:

1. Historical equity premium (HEP): historical differential return of the stock market over treasuries.

2. Expected equity premium (EEP): expected differential return of the stock market over treasuries.

3. Required equity premium (REP): incremental return of a diversified portfolio (the market) over the risk-free rate required by an investor. It is used for calculating the required return to equity.

4. Implied equity premium (IEP): the required equity premium that arises from assuming that the market price is correct.

I revise 100 textbooks on finance and valuation and find that, as shown in Table 1, different books propose different identities among the four equity premiums defined above:

- 88 claim that the REP $=$ EEP .

- 5 do not say how they calculate the REP that they use.

- Damodaran (2001a) and Arzac (2005) assume that REP = IEP.

- Penman $(2001,2003)$ maintains that "no one knows what the REP is."

- Fernández $(2002,2004)$ claims that “different investors have different REPs.”

- Black et al. (2000) calculate the EEP as an average of surveys and HEP. 


\section{Table 1}

Assumptions and recommendations of the 100 textbooks

\begin{tabular}{|l|r|r|r|c|}
\cline { 2 - 4 } \multicolumn{1}{c|}{ Assumption } & Number & \multicolumn{3}{c|}{ Recommendation } \\
\cline { 3 - 5 } \multicolumn{1}{c|}{} & of books & Max. & \multicolumn{1}{c|}{ Min. } & Average \\
\hline REP = EEP & 88 & $10.0 \%$ & $3.0 \%$ & $6.7 \%$ \\
\hline Do not say how they calculate the REP & 5 & $8.0 \%$ & $5.0 \%$ & $6.3 \%$ \\
\hline REP = IEP & 2 & $5.1 \%$ & $4.0 \%$ & $4.5 \%$ \\
\hline "No one knows what the REP is" & 2 & $6.0 \%$ & $6.0 \%$ & $6.0 \%$ \\
\hline Different investors have different REPs & 2 & $4.0 \%$ & $4.0 \%$ & $4.0 \%$ \\
\hline Average of HEP and surveys & 1 & & & $4.2 \%$ \\
\hline Total & $\mathbf{1 0 0}$ & $10.0 \%$ & $3.0 \%$ & $6.6 \%$ \\
\hline
\end{tabular}

Table 2 contains some details about the 88 books that explicitly assume that the REP is equal to the EEP:

- 59 books use the HEP as the best estimation of the EEP.

- 11 books use the HEP as a reference to calculate the EEP: 9 maintain that the EEP is higher than the HEP and 2 that it is lower.

- 11 books do not give details of how they calculate the HEP.

- Brealey and Myers (2000, 2003, 2005) “have no official position.”

- 2 claim that the EEP is proportional to the risk-free rate.

- $\quad$ Bodie and Merton (2000) calculate EEP $=\mathrm{A} \sigma^{2}{ }_{\mathrm{M}}=8 \%{ }^{1}$

- Titman and Martin (2007) use the EEP “commonly used in practice."

\section{Table 2}

Assumptions and recommendations of the 88 books that assume that REP $=$ EEP

\begin{tabular}{|c|c|c|c|c|}
\hline \multirow{2}{*}{ Assumption } & \multirow{2}{*}{$\begin{array}{l}\text { Number } \\
\text { of books }\end{array}$} & \multicolumn{3}{|c|}{ Recommendation } \\
\hline & & Max. & Min. & Average \\
\hline EEP $=$ HEP & 59 & $9.5 \%$ & $3.5 \%$ & $6.8 \%$ \\
\hline$E E P=$ arith. $H E P$ vs. $T$-Bills & 19 & $9.5 \%$ & $7.4 \%$ & $8.5 \%$ \\
\hline$E E P=$ arith. HEP vs. T-Bonds & 6 & $7.8 \%$ & $5.0 \%$ & $6.9 \%$ \\
\hline$E E P=$ geo. HEP vs. T-Bills & 8 & $8.1 \%$ & $5.3 \%$ & $6.7 \%$ \\
\hline$E E P=$ geo HEP vs. T-Bonds & 20 & $6.2 \%$ & $3.5 \%$ & $5.3 \%$ \\
\hline Do not say which HEP they use & 6 & $7.7 \%$ & $5.0 \%$ & $6.6 \%$ \\
\hline EEP $<$ HEP & 9 & $7.8 \%$ & $3.0 \%$ & $5.0 \%$ \\
\hline EEP > HEP & 2 & $9.0 \%$ & $9.0 \%$ & $9.0 \%$ \\
\hline Do not say how they get the EEP & 11 & $10.0 \%$ & $5.5 \%$ & $7.5 \%$ \\
\hline No official position & 3 & $8.0 \%$ & $8.0 \%$ & $8.0 \%$ \\
\hline REP proportional to RF & 2 & $4.2 \%$ & $4.0 \%$ & $4.1 \%$ \\
\hline $\mathrm{REP}=\mathrm{A} \sigma_{\mathrm{M}}^{2}$ & 1 & & & $8.0 \%$ \\
\hline Commonly used in practice & 1 & & & $5.0 \%$ \\
\hline Total & 88 & $10.0 \%$ & $3.0 \%$ & $6.7 \%$ \\
\hline
\end{tabular}

\footnotetext{
1 "The variance of the market portfolio $\left(\sigma_{M}^{2}\right)$ times a weighted average of the degree of risk aversion of the holders of wealth $(\mathrm{A})$. Suppose that $\sigma_{\mathrm{M}}=20 \%$ and $\mathrm{A}=2$. Then the risk premium on the market portfolio is $8 \%$."
} 
Eighty-nine of the books explicitly recommend using the CAPM for calculating the required return to equity, which is still considered, in Warren Buffett's words, "seductively precise." The CAPM assumes that REP and EEP are unique and equal.

Section 2 reviews the advice given by 100 finance and valuation textbooks about the risk premium. Section 3 comments on the four different concepts of the equity premium and mentions the most commonly used sources in the textbooks. Section 4 argues that REP and EEP may be different for different investors and provides the conclusion.

\section{The Equity Premium in The Textbooks}

Figure 1 shows the Required Equity Premium (REP) used or recommended by 100 books over the period 1979-2008 and helps to explain the confusion that many students and practitioners have about the equity premium. The average is $6.6 \%$. Figure 1 is in line with an update to Welch (2000), where it is reported that in December 2007 90\% of finance professors used equity premiums between $4 \%$ and $8.5 \%$ in their classrooms.

\section{Figure 1}

Required Equity Premium (REP) used or recommended in 100 finance and valuation textbooks, 19792008

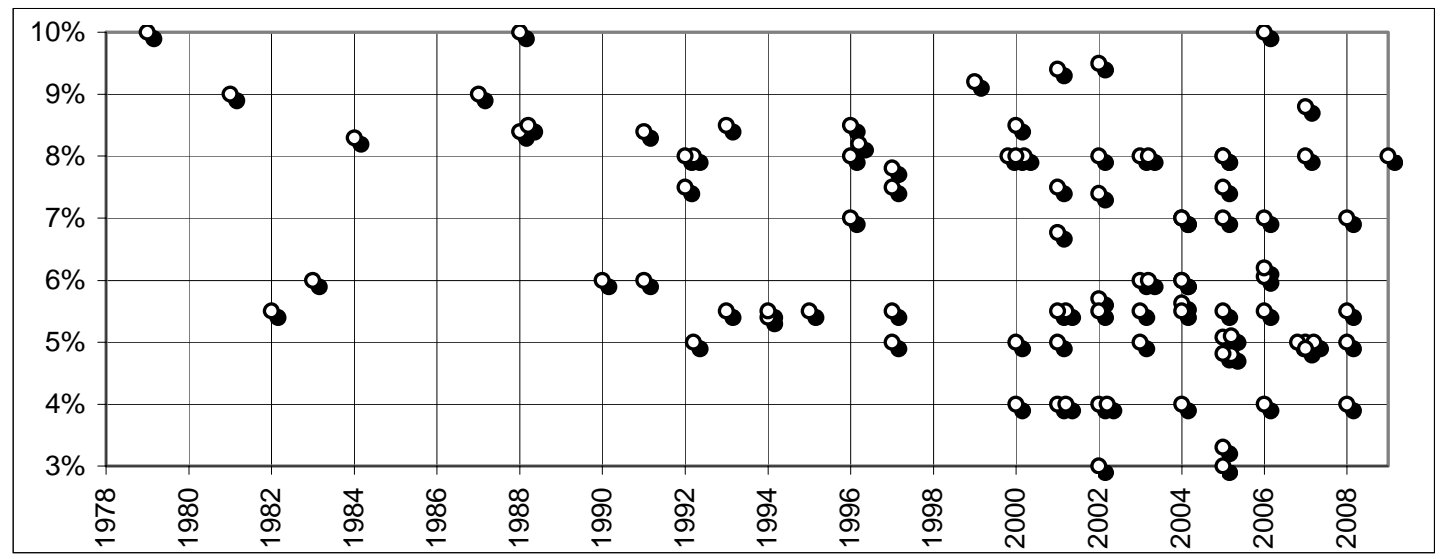

Exhibit 1 contains the main assumptions and recommendations about the equity premium in the 100 books. Now, I will briefly review the ones with the highest unit sales (according to two publishers).

Brealey and Myers considered until 1996 that REP $=$ EEP $=$ arithmetic HEP over T-Bills according to Ibbotson: 8.3\% in 1984 and 8.4\% in 1988, 1991 and 1996. In 2000 and 2003 they recognized that "Brealey and Myers have no official position on the exact market risk premium, but we believe a range of 6 to 8.5\% is reasonable for the United States." In 2005 they increased that range to " 5 to 8 percent."

Copeland, Koller and Murrin (1990 and 1995), authors of the McKinsey book on valuation, advised using a REP = geometric HEP versus Government T-Bonds, giving 6\% in 1990 and 
5.5\% in 1995. However, in 2000 and 2005 they changed criteria and advised using the arithmetic ${ }^{2}$ HEP of 2-year returns versus Government T-Bonds reduced by a survivorship bias. In 2000 they recommended $4.5-5 \%$ and in 2005 they used a REP of $4.8 \%$ because "we believe that the market risk premium as of year-end 2003 was just under 5\%."

Damodaran recommended in 1994, 1996, 1997, 2001b, 2001c and 2002 REP = EEP = geometric HEP versus T-bonds $=5.5 \% .^{3}$ In 2001a and 2006 he used a REP $=$ IEP $=4 \%$. However, in 1994 and in 1997 he calculated the cost of equity of Pepsico using REPs of 6.41\% (geometric HEP 1926-90 using T-Bills) and 8.41\% (arithmetic HEP 1926-90 using T-Bills), respectively. Damodaran (2005) used different market risk premiums: 4\%, 4.82\%, 5.5\% and 6\%.

Ross, Westerfield and Jaffe recommended in all editions that REP $=$ EEP $=$ arithmetic HEP vs. T-Bills. They recommended 8.5\% (1988, 1993 and 1996), 9.2\% (1999), 9.5\% (2002) and 8.4\% (2005). However, Ross, Westerfield and Jordan (2003a and 2003b) used different REPs: 10\%, $9.1 \%, 8.6 \%, 8 \%, 7 \%$ and 6\%.

Bodie, Kane and Marcus (1993) used a REP $=$ EEP $=6.5 \%$. In 1996 they used a REP $=$ EEP $=$ HEP $-1 \%=7.75 \% .{ }^{4}$ In 2002 they used a REP $=6.5 \%$, but in 2003 and 2005 they used different REPs: $8 \%$ and $5 \%$.

Copeland and Weston (1979 and 1988) used a REP $=10 \%$. Weston and Copeland (1992) and Copeland, Weston and Shastri (2005) used a REP $=5 \%$. Weston and Brigham (1982) affirmed that "the market risk premium can be considered relatively stable at 5 to $6 \%$ for practical application." Weston, Chung and Siu (1997) recommended 7.5\%. Weston, Mitchel and Mulherin (2004) used REP = EEP = 7\%.

Van Horne (1983) used a REP $=$ EEP $=6 \%$. In 1992, he used a REP $=5 \%$ because "the 'beforehand' or ex ante market risk premium has ranged from 3 to 7\%."

According to Penman (2001), "the market risk premium is a big guess... No one knows what the market risk premium is." In 2003 he admitted that "we really do not have a sound method to estimate the cost of capital... Estimates [of the equity premium] range, in texts and academic research, from 3.0\% to $9.2 \%$ " and used 6\%.

Bodie and Merton (2000) and Bodie, Merton and Cleeton (2009) used 8\% for USA.

Stowe, Robinson, Pinto and McLeavey (2002), in their book for the CFA (Chartered Financial Analysts) Program, used a REP = Geometric HEP using T-Bonds during 1926-2000 according to Ibbotson $=5.7 \% .^{5}$

Bruner (2004) used a REP of 6\% because "from 1926 to 2000, the risk premium for common stocks has averaged about 6\% when measured geometrically."

\footnotetext{
2 Although in the $2^{\text {nd }}$ edition they stated (page 268), "we use a geometric average of rates of return because arithmetic averages are biased by the measurement period."

3 Damodaran (2001c, page 192): "we must confess that this is more for the sake of continuity with the previous version of the book and for purposes of saving a significant amount of reworking practice problems and solutions."

${ }^{4}$ They argue that "although the HEP is a guide to the EEP one might expect from the market, there is no reason that the risk premium cannot vary somewhat from period to period."

${ }^{5}$ They also mention the "bond yield plus risk premium method." Under this approach, the cost of equity is equal to the "yield to maturity on the company's long-term debt plus a typical risk premium of 3-4\%, based on experience."
} 
Arzac (2005) used a REP of 5.08\%, the EEP calculated using a Gordon equation.

Titman and Martin (2007) mentioned that "Historical data suggest that the equity risk premium for the market portfolio has averaged 6\% to $8 \%$ a year over the past 75 years. However... for the examples of this book we will use a REP of 5\%, which is commonly used in practice."

Siegel (2002) concluded that "the future equity premium is likely to be in the range of 2 to 3\%, about one-half the level that has prevailed over the past 20 years." Siegel (2007) affirmed that "the abnormally high equity premium since 1926 is certainly not sustainable." However, in a presentation at the SIA annual meeting (November 10, 2005), Siegel maintained that "equity premium is $4 \%$ to $5 \%$ now."

Shapiro (2005, pp. 148) concluded that "an expected equity risk premium of 4 to $6 \%$ appears reasonable. In contrast, the historical equity risk premium of $7 \%$ appears to be too high for current conditions." However, he used different REPs in his examples: 5\%, 7.5\% and 8\%.

\section{Four Different Concepts}

The four concepts (HEP, REP, EEP and IEP) refer to different things ${ }^{7}$. The HEP is easy to calculate and is the same for all investors, provided they use the same time frame, the same market index, the same risk-free instrument and the same average (arithmetic or geometric). The EEP, the REP and the IEP, in contrast, may be different for different investors and are not observable magnitudes.

\subsection{Historical Equity Premium (HEP)}

The HEP is the historical average differential return of the market portfolio over risk-free debt. The most widely cited sources are: Ibbotson Associates, whose U.S. database starts in 1926; Dimson et al. (2007), who calculate the HEP for 17 countries over 106 years (1900-2005); and the Center for Research in Security Prices (CRSP) at the University of Chicago. Forty books use data from Ibbotson, 6 from Dimson et al., 3 from CRSP, 10 use their own data, and the rest do not say which data they use.

Table 2 shows that the recommendations in the 59 books which assume that REP $=$ EEP $=$ HEP ranges from 3.5\% to 9.5\%. This huge range is partly due to the type of average and the riskfree instrument used in each book, but there also significant differences (ranges wider than 2\%) among the books that use the same average and the same risk-free instrument.

As shown in Table 3, however, even using the same time frame, average and risk-free instrument, different authors do not get the same result for the HEP. The differences are mainly due to the stock indexes chosen.

\footnotetext{
${ }^{6}$ Siegel also affirms that: "Although it may seem that stocks are riskier than long-term government bonds, this is not true. The safest investment in the long run (from the point of view of preserving the investor's purchasing power) has been stocks, not Treasury bonds."

${ }^{7}$ We agree with Bostock (2004) when he says that "understanding the equity premium is largely a matter of using clear terms."
} 


\section{Table 3}

Different Historical Equity Premiums (HEP) according to different authors

\begin{tabular}{|l|l|l|l|l|l|l|}
\cline { 3 - 7 } \multicolumn{2}{c|}{} & \multicolumn{5}{c|}{ U.S. 1926-2005 } \\
\cline { 3 - 7 } \multicolumn{2}{c|}{} & Ibbotson & Shiller & WJ & Damodaran & Siegel \\
\hline $\begin{array}{l}\text { HEP vs. } \\
\text { LT Gov. } \\
\text { Bonds }\end{array}$ & Geometric & $4.9 \%$ & $5.5 \%$ & $4.4 \%$ & $5.1 \%$ & $4.6 \%$ \\
\cline { 2 - 7 } & Arithmetic & $6.5 \%$ & $7.0 \%$ & $5.8 \%$ & $6.7 \%$ & $6.1 \%$ \\
\hline $\begin{array}{l}\text { HEP vs. } \\
\text { T-Bills }\end{array}$ & Geometric & $6.7 \%$ & $6.0 \%$ & $6.2 \%$ & $6.3 \%$ & $6.2 \%$ \\
\cline { 2 - 7 } & Arithmetic & $8.5 \%$ & $7.7 \%$ & $7.9 \%$ & $8.2 \%$ & $8.2 \%$ \\
\hline
\end{tabular}

\begin{tabular}{|c|l|l|l|l|}
\hline \multicolumn{5}{|c|}{ Dimson et al. 1900-2005 } \\
\hline U.S. & Germany & Spain & $\begin{array}{c}\text { Average 17 } \\
\text { countries }\end{array}$ & $\begin{array}{c}\text { World ex } \\
\text { U.S. }\end{array}$ \\
\hline $4.5 \%$ & $5.3 \%$ & $2.3 \%$ & $4.0 \%$ & $4.1 \%$ \\
\hline $6.5 \%$ & $8.4 \%$ & $4.2 \%$ & $6.1 \%$ & $5.2 \%$ \\
\hline $5.5 \%$ & $3.8 \%$ & $3.4 \%$ & $4.8 \%$ & $4.2 \%$ \\
\hline $7.4 \%$ & $9.1 \%$ & $5.5 \%$ & $7.1 \%$ & $5.9 \%$ \\
\hline
\end{tabular}

Sources: Ibbotson Associates (2006). http://aida.econ.yale.edu/ shiller/data.htm. WJ: updated from Wilson and Jones (2002). Damodaran: http://pages.stern.nyu.edu/ adamodar/. Siegel: updated from Siegel (2005). Dimson et al.: Table 3 of Dimson, Marsh and Staunton (2007).

The estimates of Dimson et al. (2007) (see Table 3) incorporate the earlier part of the $20^{\text {th }}$ century as well as the opening years of the $21^{\text {st }}$ century, but, as the authors point out, "virtually all of the 16 countries experienced trading breaks ... often in wartime" (World War I, World War II, Spanish Civil War, etc.). They claim that "we were able to bridge these gaps," but this assertion is questionable ${ }^{8}$.

\subsection{Expected Equity Premium (EEP)}

Some authors try to find the EEP by conducting surveys. Welch (2000) performed two surveys with finance professors in 1997 and 1998, asking them what they thought the EEP would be over the next 30 years. He obtained 226 replies, ranging from 1\% to 15\%, with an arithmetic average EEP of 7\% above T-Bonds. ${ }^{9}$ Welch (2001) presented the results of a survey of 510 finance and economics professors performed in August 2001, where the consensus for the 30year arithmetic EEP was 5.5\%, much lower than just 3 years earlier. In an update published in 2008 , the mean was $5.69 \%$, but the estimates of about 400 finance professors ranged from $2 \%$ to $12 \%$. Welch also reports that the equity premium "used in class" in December 2007 averaged $5.89 \%$ and that $90 \%$ of the professors used equity premiums between $4 \%$ and $8.5 \%$.

Graham and Harvey (2007) indicate that U.S. CFOs reduced their average 10-year EEP from $4.65 \%$ in September 2000 to $2.5 \%$ by September 2006. However, the standard deviation of the 465 responses in 2006 was 2.47\%. Goldman Sachs (0’Neill, Wilson and Masih, 2002) conducted a survey of its global clients in July 2002 and found that the average long-run EEP was 3.9\%, with most responses between 3.5\% and 4.5\%. The magazine Pensions and Investments (12/1/1998) carried out a survey among professionals working for institutional investors and found an average EEP of 3\%.

\footnotetext{
${ }^{8}$ Dimson et al. (2007) explain in their footnote 7 that: "In Spain, trading was suspended during the Civil War from July 1936 to April 1939, and the Madrid exchange remained closed through February 1940; over the closure we assume a zero change in nominal stock prices and zero dividends." They also mention an "unbridgeable discontinuity, namely, bond and bill (but not equity) returns in Germany during the hyperinflation of 1922-23, when German bond and bill investors suffered a total loss of $-100 \%$. ... When reporting equity premiums for Germany ... we thus have no alternative but to exclude the years 1922-23."

9 At that time, the most recent Ibbotson Associates Yearbook reported an arithmetic average HEP versus T-bills of 8.9\% (1926-1997).
} 


\section{Table 4}

Estimates of the EEP (Expected Equity Premium) according to different surveys

\begin{tabular}{|lcl|}
\hline Authors & Conclusion about EEP & Respondents \\
\hline Pensions and Investments (1998) & $3 \%$ & Institutional investors \\
Graham and Harvey (2007) & Sep. 2000. Mean: 4.65\%. Std. Dev. $=2.7 \%$ & CFOs \\
Graham and Harvey (2007) & Sep. 2006. Mean: 2.93\%. Std. Dev. $=2.47 \%$ & CFOs \\
Welch (2000) & Oct. 1997. Mean: 7\%. Range from 2\% to 13\% & Finance professors \\
& August 2001. Mean: 5.5\%. Range from 0\% to & \\
Welch (2001) & $25 \%$ & Finance professors \\
Welch update & December 2007. Mean: 5.69\%. Range 2\% to 12\% & Finance professors \\
O'Neill, Wilson and Masih (2002) & $3.9 \%$ & Global clients Goldman \\
\hline
\end{tabular}

An anecdote from Merton Miller (2000, page 3) about the expected market return in the Nobel context: "I still remember the teasing we financial economists, Harry Markowitz, William Sharpe, and I, had to put up with from the physicists and chemists in Stockholm when we conceded that the basic unit of our research, the expected rate of return, was not actually observable. I tried to tease back by reminding them of their neutrino - a particle with no mass whose presence was inferred only as a missing residual from the interactions of other particles. But that was eight years ago. In the meantime, the neutrino has been detected."

I report in Table 1 that 88 books explicitly affirm that REP $=$ EEP. Fifty-nine of them assume that REP $=\mathrm{EEP}=\mathrm{HEP}$ and that the historical record provides an adequate guide for future expected long-term behavior. However, as the abovementioned surveys report, the EEP changes over time and has a great dispersion, so it is not clear why averages from past decades should determine expected returns in the $21^{\text {st }}$ century.

Numerous papers and books assert or imply that there is a "market" EEP. However, investors and professors do not share "homogeneous expectations," do not hold the same portfolio of risky assets and may have different assessments of the expected equity premium. Tables 2 and 4 also suggest that different investors have different EEPs.

In order for all investors to share a common EEP, we would have to assume homogeneous expectations (or a representative investor). Given what we know about financial markets, however, this is not a reasonable assumption. With homogeneous expectations it is also difficult to explain why the annual trading volume of most exchanges is more than double their market capitalization.

\subsection{Required Equity Premium (REP)}

The required equity premium (REP) is the answer to the following question: What incremental return do I require for investing in a diversified portfolio of shares (a stock index, for example) rather than at the risk-free rate? It is a crucial parameter because the REP is the key to determining a company's required return to equity, WACC and required return to any investment project.

Different investors and different companies may, and in fact do, use different REPs. Many valuations cite one or other of the 100 books we have analyzed as the source of the equity premium they use. Given the dispersion of these books' recommendations, as reflected in Figure 1 , it is not surprising that different investors use different REPs. 


\subsection{Implied Equity Premium (IEP)}

The IEP is the implicit REP used in the valuation of a stock (or market index) that matches the current market value. The most widely used model to calculate the IEP is the dividend discount model. According to this model, the current price per share $\left(P_{0}\right)$ is the present value of expected dividends discounted at the required rate of return $(\mathrm{Ke})$. If $d_{1}$ is the dividend (equity cash flow) per share expected to be received at time 1 , and $g$ the expected long-term growth rate in dividends per share,

$P_{0}=d_{1} /(K e-g)$, which implies: IEP $=d_{1} / P_{0}+g-R_{F}$

Fama and French (2002), using a discounted dividend model, estimated the IEP for the period 1951-2000 to be between 2.55\% and 4.32\%, far below the HEP (7.43\%). For the period 18721950, they estimated an IEP (4.17\%) similar to the HEP (4.4\%).

The estimates of the EEP depend on the particular assumption made for expected growth. Even if market prices are correct for all investors, there is no IEP that is common to all investors: there are many pairs (IEP, $g$ ) that satisfy equation (1). If equation (1) holds, the expected return for shareholders is equal to the required return for shareholders $(K e)$, but there are many required returns (as many as expected growths, $g$ ) in the market. Many papers in the financial literature report different estimates of the IEP, with great dispersion. Examples include 0'Hanlon and Steele (2000, IEP $=4$ to 6\%), Jagannathan et al. $(2000$, IEP $=3.04 \%)$, Claus and Thomas $(2001$, IEP $=3 \%$ ), Harris and Marston $(2001$, IEP $=7.14 \%)$, Goedhart et al. $(2002$, 5\% 1962-79 and 3.6\% in 1990-2000), Ritter and Warr (2002, IEP = 12 in 1980 and -2\% in 1999) and Harris et al. $(2003$, IEP $=7.3 \%)$.

It seems that there is no common IEP in the market: different investors may have different IEPs and use different REPs. A unique IEP requires assuming homogeneous expectations for expected growth $(g)$, but there several pairs (IEP, $g$ ) that satisfy current prices.

For any particular investor, the REP and the IEP are equal. The EEP is not necessarily equal to the REP (unless the investor considers that the market price is equal to the value of the shares). Obviously, an investor will hold shares if his EEP is higher than (or equal to) his REP, and not otherwise. We can find out the REP and the EEP of an investor by asking him, although for many investors the REP is not an explicit parameter but is implicit in the price they are prepared to pay for the shares. However, it is impossible to determine the REP for the market as a whole, because there is no such thing: even if we knew the REPs of all the investors in the market, it would be meaningless to talk of a REP for the market as a whole. The REP is a distribution and all we can say is that a certain percentage of investors have REPs contained in a range. The average of that distribution cannot be interpreted as the REP of the market.

The rationale for this is to be found in the aggregation theorems of microeconomics, which in actual fact are non-aggregation theorems. One model that works well individually for a number of people may not work for all of the people together ${ }^{10}$.

Which equity premium should I use? In most of the valuations I have done in the $21^{\text {st }}$ century I have used REPs between 3.8 and 4.3\% for Europe and for the U.S. Given the yields of T-Bonds,

\footnotetext{
${ }^{10}$ According to Mas-Colell et al. (1995, page 120), "it is not true that whenever aggregate demand can be generated by a representative consumer, this representative consumer's preferences have normative contents. It may even be the case that a positive representative consumer exists but that there is no social welfare function that leads to a normative representative consumer."
} 
I (and most of my students and clients) think that an additional 4\% compensates the additional risk of a diversified portfolio.

\section{Conclusion}

The equity premium recommendations of 100 finance and valuation textbooks published between 1979 and 2008 range from 3\% to 10\%. Several books use different equity premia on different pages. Most books do not distinguish among the four different concepts that the term equity premium designates: historical equity premium, expected equity premium, required equity premium and implied equity premium.

It is quite clear that there is no generally accepted equity premium point estimate. Nor is there a common method to estimate the equity premium, not even for the HEP.

Different investors may have different REPs and different EEPs. A unique IEP would require assuming homogeneous expectations for expected growth $(g)$, but there are several pairs (IEP, $g$ ) that satisfy current prices. We could only talk of an EEP $=$ REP $=$ IEP if all investors had the same expectations. If they did, it would make sense to talk of a market risk premium and all investors would have the market portfolio. However, expectations are not homogeneous.

Different investors have different expectations of equity cash flows and different evaluations of their risk (which translate into different discount rates, different REPs and different EEPs). For any given company there will be investors who think that the company is undervalued (and who will therefore buy or hold shares); investors who think that the company is overvalued (and so will sell or not buy shares); and investors who think that the company is fairly valued (and so will sell or hold shares). The investors who did the last trade, or the rest of the investors that held or did not have shares, have neither a common REP nor common expectations regarding the equity cash flows.

Finance textbooks should clarify the equity premium by giving distinguishing definitions of the four different concepts and conveying a clearer message about their sensible magnitudes. 


\section{References}

Adair, T. (2005), Corporate Finance Demystified, $1^{\text {st }}$ edition, McGraw-Hill.

Antill, N. and K. Lee (2008), Company Valuation Under IFRS, Harriman House Publishing.

Arzac, Enrique R. (2005), Valuation for Mergers, Buyouts, and Restructuring, $1^{\text {st }}$ edition, John Wiley \&t Sons Inc.

Benninga, S. Z. and O. H Sarig (1997), Corporate Finance: A Valuation Approach, McGrawHill/Irwin.

Berk, J., P. DeMarzo and J. Harford (2008), Fundamentals of Corporate Finance, Pearson Education.

Bodie, Z. and R. Merton (2000), Finance, New Jersey: Prentice Hall.

Bodie, Z., R. Merton and D. L. Cleeton (2009), Financial Economics, $2^{\text {nd }}$ edition, Pearson, International edition.

Bodie, Z., A. Kane and A. J. Marcus (2004), Investments, $6^{\text {th }}$ edition. New York: McGraw Hill. Previous editions: 1989, 1993, 1996, 1999, 2002.

Bodie, Z., A. Kane and A. J. Marcus (2003), Essentials of Investments, $5^{\text {th }}$ edition, New York: McGraw Hill.

Bostock, P. (2004), “The Equity Premium,” Journal of Portfolio Management 30(2): 104-111.

Black, A., P. Wright and J. Bachman (2000), In Search of Shareholder Value. Managing the Drivers of Performance, $2^{\text {nd }}$ edition, Financial Times Prentice Hall.

Brealey, R. A. and S. C. Myers (2003), Principles of Corporate Finance, $7^{\text {th }}$ edition, New York: McGraw-Hill. Previous editions: 1981, 1984, 1988, 1991, 1996 and 2000.

Brealey, R. A., S. C. Myers and F. Allen (2005), Principles of Corporate Finance, $8^{\text {th }}$ edition, McGraw-Hill/Irwin.

Bruner, Robert F. (2004), Applied Mergers and Acquisitions, New York: John Wiley \& Sons.

Butler, K. C. (2000), Multinational Finance, $2^{\text {nd }}$ edition, South-Western College Pub.

Butters, J. K., W. E. Fruhan, D. W. Mullins and T. R. Piper (1987), Case Problems in Finance, $9^{\text {th }}$ edition, Richard D. Irwin, Inc. Previous editions: $8^{\text {th }}$ in $1981 ; 7^{\text {th }}$ in 1975.

Claus, J. J. and J. K. Thomas (2001), "Equity Premia as Low as Three Percent? Evidence from Analysts' Earnings Forecasts for Domestic and International Stock Markets," Journal of Finance 55(5): 1629-66.

Copeland, T. E., T. Koller and J. Murrin (2000), Valuation: Measuring and Managing the Value of Companies, $3^{\text {rd }}$ edition, New York: Wiley. Previous editions: 1990 and 1995.

Copeland, T. E. and J. F. Weston (1988), Financial Theory and Corporate Policy, $3^{\text {rd }}$ edition, Reading, MA: Addison-Wesley. $1^{\text {st }}$ edition: 1979.

Copeland, T. E., J. F. Weston and K. Shastri (2005), Financial Theory and Corporate Policy, $4^{\text {th }}$ edition, Pearson Addison-Wesley. 
Cowles, A. (1939), Common Stock Indexes, Bloomington, IN: Principia Press.

Damodaran, A. (2006), Damodaran on Valuation, $2^{\text {nd }}$ edition, New York: John Wiley and Sons. $1^{\text {st }}$ edition: 1994.

Damodaran, A. (2001a), The Dark Side of Valuation, New York: Prentice-Hall.

Damodaran, A. (2001b), Corporate Finance: Theory and Practice, $2^{\text {nd }}$ edition, New York: John Wiley and Sons.

Damodaran, A. (2001c), Corporate Finance: Theory and Practice, $2^{\text {nd }}$ international edition, New York: John Wiley and Sons.

Damodaran, A. (2002), Investment Valuation, $2^{\text {nd }}$ edition, New York: John Wiley and Sons. $1^{\text {st }}$ edition: 1996.

Damodaran, A. (2005), Applied Corporate Finance: A User's Manual, $2^{\text {nd }}$ edition, Wiley.

Dimson, E., P. Marsh and M. Staunton (2006a), Global Investment Returns Yearbook 2006, ABN AMRO/London Business School.

Dimson, E., P. Marsh and M. Staunton (2006b), DMS Global Returns data module, Chicago, IL: Ibbotson Associates.

Dimson, E., P. Marsh and M. Staunton (2007), "The Worldwide Equity Premium: A Smaller Puzzle," in Handbook of investments: Equity risk premium, R. Mehra, Elsevier.

English, J. (2001), Applied Equity Analysis: Stock Valuation Techniques for Wall Street Professionals, $1^{\text {st }}$ edition, McGraw-Hill.

Estrada, J. (2006), Finance in a Nutshell, Financial Times Prentice Hall Press.

Evans, F. C. and D. M. Bishop (2001), Valuation for M\&A: Building Value in Private Companies, $1^{\text {st }}$ edition, Wiley.

Feldman, S. J (2005), Principles of Private Firm Valuation, $1^{\text {st }}$ edition, Wiley.

Fernández, P. (2002), Valuation Methods and Shareholder Value Creation, San Diego, CA: Academic Press.

Fernández, P. (2006), “Equity Premium: Historical, Expected, Required and Implied,” IESE Business School Working paper, SSRN no. 933070.

Fruhan, W. E., W. C. Kester, S. P. Mason, T. R. Piper and R. S. Ruback (1992), Case Problems in Finance, $10^{\text {th }}$ edition, Richard D. Irwin, Inc.

Goedhart, M., T. Koller and D. Wessels (2002), "The real cost of Equity," McKinsey \& Company 5, Autumn, pp. 11-15.

Goetzmann, W. N. and R. G. Ibbotson (2006), The Equity Risk Premium: Essays and Explorations, Oxford University Press, USA.

Graham, J. R. and C. R. Harvey (2007), "The Equity Risk Premium in January 2007: Evidence from the Global CFO Outlook Survey," Icfai Journal of Financial Risk Management IV(2): 46-61. 
Guerard, J. B. and E. Schwartz (2007), Quantitative Corporate Finance, $1^{\text {st }}$ edition, Springer.

Harris, R. S. and F. C. Marston (2001), "The Market Risk Premium: Expectational Estimates Using Analysts' Forecasts," Journal of Applied Finance 11.

Harris, R. S., F. C. Marston, D. R. Mishra and T. J. O’Brien (2003), "Ex Ante Cost of Equity Estimates of SctP 500 Firms: The Choice Between Global and Domestic CAPM," Financial Management 32(3), Autumn.

Hawawini, G. and C. Viallet (2002), Finance for Executives, $2^{\text {nd }}$ edition, South-Western, Thompson Learning.

Hitchner, J. R. (2006), Financial Valuation: Applications and Models, Wiley Finance.

Ibbotson Associates (2006), Stocks, Bonds, Bills, and Inflation, Valuation Edition, 2006 Yearbook.

Ibbotson, R. (2002), TIAA-CREF Investment Forum, June.

Jacquier, E., A. Kane and A. J. Marcus (2003), "Geometric or Arithmetic Mean: A Reconsideration," Financial Analysts Journal 59(6): 46-53.

Jagannathan, R., E. R. McGrattan and A. D. Shcherbina (2000), "The Declining U.S. Equity Premium," Federal Reserve Bank of Minneapolis Quarterly Review 24: 3-19.

Jones, C. P. (2006), Investments: Analysis and Management, $10^{\text {th }}$ edition, Wiley. $5^{\text {th }}$ edition: 1996.

Jorion, P. and W. N. Goetzmann (1999), "Global stock markets in the twentieth century," Journal of Finance 54 (June): 953-80.

Kasper L. J. (1997), Business Valuations: Advanced Topics, Quorum Books.

Kester, W. C., R. S. Ruback and P. Tufano (2005), Case Problems in Finance, $12^{\text {th }}$ edition, McGraw-Hill Int.

Kim, S. and S. Kim (2006), Global Corporate Finance: Text and Cases, $6^{\text {th }}$ edition, WileyBlackwell.

Koller, T., Goedhart, M. and D. Wessels (2005), Valuation: Measuring and Managing the Value of Companies, 4th edition, McKinsey \&t Company, Inc. Wiley.

Li, H. and Y. Xu (2002), “Survival Bias and the Equity Premium Puzzle," Journal of Finance 57: 1981-1993.

Lumby, S. and C. Jones (2003), Corporate Finance: Theory and Practice, $7^{\text {th }}$ edition, Cengage Lrng Business Press.

Martin, J. D. and J. W. Petty (2000), Value Based Management, Boston: Harvard Business School Press.

Mas-Colell, A., M. D. Whinston and J. R. Green (1995), Microeconomic Theory, Oxford University Press.

Miller, M. H. (2000), “The History of Finance: An Eyewitness Account," Journal of Applied Corporate Finance 13(2): 8-14.

12 - IESE Business School-University of Navarra 
Moyer, R. C., J. R. McGuigan and W. J. Kretlow (2001), Contemporary Financial Management, 8th edition, South-Western College Pub.

O'Hanlon, J. and A. Steele (2000), "Estimating the Equity Risk Premium Using Accounting Fundamentals," Journal of Business Finance \&t Accounting 27 (9ct10): 1051-1083.

O'Neill, J., D. Wilson and R. Masih (2002), "The Equity Risk Premium from an Economics Perspective," Goldman Sachs, Global Economics Paper no. 84.

Palepu, K. G. and P. M. Healy (2007), Business Analysis and Valuation: Using Financial Statements, $4^{\text {th }}$ edition, South-Western College Pub.

Penman, S. H. (2003), Financial Statement Analysis and Security Valuation, $2^{\text {nd }}$ edition, McGraw-Hill. $1^{\text {st }}$ edition: 2001.

Pereiro, L. E. (2002), Valuation of Companies in Emerging Markets, $1^{\text {st }}$ edition, Wiley.

Pettit, J. (2007), Strategic Corporate Finance: Applications in Valuation and Capital Structure, Wiley.

Pratt, S. P. (2002), Cost of Capital: Estimation and Applications, $2^{\text {nd }}$ edition, Wiley.

Ritter, J. R. and R. Warr (2002), "The Decline of Inflation and the Bull Market of 1982 to 1999," Journal of Financial and Quantitative Analysis 37(1): 29-61.

Ross, S. A., R. W. Westerfield and J. F. Jaffe (2005), Corporate Finance, $7^{\text {th }}$ edition, Homewood, IL: McGraw-Hill/Irwin. Previous editions: 1998, 1993, 1996, 1999 and 2002.

Ross, S. A., R. W. Westerfield and B. D. Jordan (2003a), Essentials of Corporate Finance, $4^{\text {th }}$ edition, McGraw-Hill/Irwin.

Ross, S. A., R. W. Westerfield and B. D. Jordan (2003b), Fundamentals of Corporate Finance, $6^{\text {th }}$ edition, McGraw-Hill/Irwin.

Ryan, R. (2006), Corporate Finance and Valuation, $1^{\text {st }}$ edition, Cengage Lrng Business Press.

Shapiro, A. C. (2005), Capital Budgeting and Investment Analysis, Pearson, Prentice Hall.

Shiller, R. J. (2000), Irrational Exuberance, Princeton, New Jersey: Princeton University Press.

Siegel, J. J. (2005), "Perspectives on the Equity Risk Premium," Financial Analysts Journal 61(6): 61-71.

Siegel, J. (2007), Stocks for the Long Run, $4^{\text {th }}$ edition, New York: Irwin. Previous editions: 1994, 1998, 2002.

Smart, S. and W. L. Megginson (2008), Corporate Finance, Thomson Learning.

Stewart, G. B. (1991), The Quest for Value. The EVA Management Guide. Harper Business.

Stowe, J. D., T. R. Robinson, J. E. Pinto and D. W. McLeavey (2002), Analysis of Equity investments: Valuation. AIMR (Association for Investment Management and Reasearch).

Tham, J. and I. Vélez-Pareja (2004), Principles of Cash Flow Valuation: An Integrated MarketBased Approach, $1^{\text {st }}$ edition, Academic Press. 
Titman, S. and J. D. Martin (2007), Valuation: The Art and Science of Corporate Investment Decisions, Pearson, Addison Wesley.

Van Horne, J. C. (1986), Fundamentals of Financial Management and Policy, $6^{\text {th }}$ edition, Englewood Cliffs, NJ: Prentice-Hall. Previous editions: 1971, 1974, 1977, 1980 and 1983.

Van Horne, J. C. (1992), Financial Management and Policy, $9^{\text {th }}$ edition, Englewood Cliffs, NJ: Prentice-Hall. Previous editions: 1968, 1971, 1974, 1977, 1980, 1983.

Viebig, J., A. Varmaz and T. Poddig (2008), Equity Valuation: Models from Leading Investment Banks, Wiley Finance Series

Weaver, S. C., J. F. Weston and S. Weaver (2004), Finance \& Accounting for Non-Financial Managers, $1^{\text {st }}$ edition, McGraw-Hill.

Welch, I. (2000), "Views of Financial Economists on the Equity Premium and on Professional Controversies," Journal of Business 73(4): 501-537.

Welch, I. (2001), "The Equity Premium Consensus Forecast Revisited," Cowles Foundation Discussion Paper no. 1325, SSRN no. 285169.

Weston, J. F. and E. F. Brigham (1968), Essentials of Managerial Finance, Holt, Rinehart and Winston.

Weston, J. F. and T. E. Copeland (1992), Managerial Finance, $9^{\text {th }}$ edition, The Dryden Press.

Weston, J. F., S. Chung and J. A. Siu (1997), Takeovers, Restructuring and Corporate Governance, $2^{\text {nd }}$ edition, New Jersey: Prentice-Hall.

Weston, J. F., M. L. Mitchel and J. H. Mulherin (2004), Takeovers, Restructuring, and Corporate Governance, $4^{\text {th }}$ edition, Pearson Education, Prentice Hall.

Weston, J. F., S. C. Weaver and S. Weaver (2004), Mergers \&t Acquisitions, $1^{\text {st }}$ edition, McGrawHill.

White, R. W. (1994), Case Studies in Modern Corporate Finance, Prentice-Hall

\section{References in Spanish}

Adsera, X. and P. Vinolas (1997), Principios de valoracion de empresas, Editorial Deusto.

Fernández, P. (2004), Valoracion de Empresas, $3^{\text {rd }}$ edition, Ediciones Gestion 2000. $2^{\text {nd }}$ edition: 2001.

Lopez Lubian, F. J. and W. de Luna (2001), Valoracion de Empresas en la Practica, Madrid: McGraw Hill Interamericana.

Lopez Lubian, F. J. and P. García (2005), Finanzas en el mundo corporativo. Un enfoque práctico, Madrid: McGraw Hill Interamericana.

Marín, J. M. and G. Rubio (2001), Economía Financiera, Antoni Bosch, editor.

Mascarenas, J. (1993), Manual de Fusiones y Adquisiciones de Empresas, Madrid: McGraw Hill Interamericana. 
Mascarenas, J. (2004), El Riesgo en la Empresas, Madrid: Ediciones Piramide.

Mascarenas, J. (2005), Fusiones y Adquisiciones de Empresas, $4^{\text {th }}$ edition, Madrid: McGraw Hill.

Rojo, A. (2007), Valoración de empresas y gestion basada en valor, Editorial Thompson Paraninfo.

Sanjurjo, M. and M. Reinoso (2003), Guia de Valoracion de Empresas, Pearson Educación. 


\section{Exhibit 1}

Equity premiums recommended and used in textbooks

\begin{tabular}{|c|c|c|c|c|c|c|}
\hline & Author(s) of the Textbook & Assumption & $\begin{array}{c}\text { Period for } \\
\text { HEP }\end{array}$ & $\begin{array}{c}\text { REP } \\
\text { recommended }\end{array}$ & REP used & Pages in thetext book \\
\hline $\begin{array}{l}\text { Brealey and } \\
\text { Myers }\end{array}$ & $\begin{array}{l}\text { 2nd edition. } 1984 \\
\text { 3rd edition. } 1988 \\
\text { 4th edition. } 1991 \\
\text { 5th edition. } 1996 \\
\text { 6th edition. } 2000 \\
\text { 7th edition. } 2003 \\
\text { 8th edition. } 2005 \text { (with Allen) } \\
\end{array}$ & 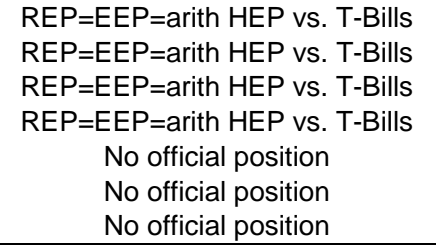 & $\begin{array}{l}1926-81 \\
1926-85 \\
1926-88 \\
1926-95\end{array}$ & $\begin{array}{c}8.3 \% \\
8.4 \% \\
8.4 \% \\
8.4 \% \\
6.0-8.5 \% \\
6.0-8.5 \% \\
5.0-8 \% \\
\end{array}$ & $\begin{array}{l}8.3 \% \\
8.4 \% \\
8.4 \% \\
8.4 \% \\
8.0 \% \\
8.0 \% \\
6-8.5 \% \\
\end{array}$ & $\begin{array}{c}119,132 .^{11} \\
126,139,140,185 \\
131,194,196 \\
180,181,218 \\
160,195 \\
160,195^{12} \\
75,154^{13}, 178(8.5 \%) ; 222(8 \%) ; 229(6 \%)\end{array}$ \\
\hline $\begin{array}{l}\text { Copeland, } \\
\text { Koller and } \\
\text { Murrin } \\
\text { (McKinsey) }\end{array}$ & $\begin{array}{l}\text { 1st edition. } 1990 \\
\text { 2nd ed. } 1995 \\
\text { 3rd ed. } 2000 \\
\text { 4th ed. } 2005 . \text { Goedhart, Koller \& Wessels }\end{array}$ & $\begin{array}{c}\mathrm{REP}=\mathrm{EEP}=\text { geo HEP vs. T-Bonds } \\
\mathrm{REP}=\mathrm{EEP}=\text { geo HEP vs. T-Bonds } \\
\mathrm{REP}=\mathrm{EEP}=\text { arith HEP }-1.5-2 \% \\
\mathrm{REP}=\mathrm{EEP}=\text { arith HEP }-1-2 \%\end{array}$ & $\begin{array}{c}1926-88 \\
1926-92 \\
1926-98 \\
1903-2002 \\
\end{array}$ & $\begin{array}{c}5-6 \% \\
5-6 \% \\
4.5-5 \% \\
3.5-4.5 \% \\
\end{array}$ & $\begin{array}{c}6 \% \\
5.5 \% \\
5 \% \\
4.8 \% \\
\end{array}$ & $\begin{array}{c}193(5-6 \%) ; 205(6 \%) ; 196^{14} \\
268 \\
221(4.5-5 \%) ; 231(5 \%)^{15} \\
297 \text { (REP=EEP); } 298^{16} ; 539(4.8 \%) ; 303^{17}\end{array}$ \\
\hline
\end{tabular}

11 (1984, page 119), (1988, page 127) and (1991, page 131): "the crucial assumption here is that there is a normal, stable risk premium on the market portfolio, so that the expected future risk premium can be measured by the average past risk premium. One could quarrel with this assumption, but at least it yields estimates of the market return that seem sensible."

12 "How about the market risk premium? As we have pointed out in the last chapter, we can't measure EEP with precision. From past evidence it appears to be about 9\%, although many economists and financial managers would forecast a lower figure. Let's use $8 \%$ in this example."

13 "Brealey, Myers and Allen have no official position on the exact market risk premium, but we believe that a range of 5 to 8 percent is reasonable for the risk premium in the United States." "It seems that the EEP over this period was ... 5.3\%. This is 2.3\% lower than the realized risk premium in the period 1900-2003."

14 "Our opinion is that the best forecast of the risk premium is its long-run geometric average." Ibbotson geometric HEP vs. T-Bonds in the period 1926-1988 was 5.4\% (page194).

15 "It is unlikely that the U.S. Market index will do as well over the next century as it has in the past, so we adjust downward the historical arithmetic average market risk premium. If we substract a 1.5 to $2 \%$ survivorship bias from the long-term arithmetic average of 6.5\%, we conclude that the market risk premium should be in the $4.5-5 \%$ range." $6.5 \%$ was the arithmetic HEP of 2-year returns in the period 1926-1998 (page 220). The geometric HEP of 1-year returns was 5.9\%.

16 "we believe that the market risk premium as of year-end 2003 was just under 5\%."

17 "Using data from Jorion and Goetzmann, we find that between 1926 and 1996, the U.S. arithmetic annual return exceeded the median return on a set of 11 countries with continuous histories dating to the 1920 s by $1.9 \%$ in real terms, or 1.4\% in nominal terms. If we subtract a $1 \%$ to $2 \%$ survivorship bias from the long-term arithmetic average of 5.5 percent (arithmetic mean of 10-year holding period returns from 1903 to 2002) the difference implies the future range of the U.S. market risk premium should be 3.5\% to 4.5\%."

16 - IESE Business School-University of Navarra 


\section{Exhibit 1 (continued)}

Equity premiums recommended and used in textbooks

\begin{tabular}{|c|c|c|c|c|c|c|}
\hline \multicolumn{2}{|c|}{ Author(s) of the Textbook } & Assumption & $\begin{array}{c}\text { Period for } \\
\text { HEP }\end{array}$ & $\begin{array}{c}\text { REP } \\
\text { recommended }\end{array}$ & REP used & Pages in the textbook \\
\hline \multirow{6}{*}{$\begin{array}{l}\text { Ross, } \\
\text { Westerfield } \\
\text { and Jaffe }\end{array}$} & 2nd edition. 1988 & REP $=$ EEP $=$ arith HEP vs. T-Bills & $1926-88$ & $8.5 \%$ & $8.5 \%$ & $243-4,287^{18}$ \\
\hline & 3rd edition. 1993 & REP $=$ EEP $=$ arith HEP vs. T-Bills & $1926-93$ & $8.5 \%$ & $8.5 \%$ & \\
\hline & 4th edition. 1996 & REP $=$ EEP $=$ arith HEP vs. T-Bills & $1926-94$ & $8.5 \%$ & $8.5 \%$ & 241,280 \\
\hline & 5th edition. 1999 & REP $=$ EEP $=$ arith HEP vs. T-Bills & $1926-97$ & $9.2 \%$ & $9.2 \%$ & $259^{19}, 261$ \\
\hline & 6th edition. 2002 & REP $=$ EEP $=$ arith HEP vs. T-Bills & $1926-99$ & $9.5 \%$ & $9.5 \%$ & $259,274,324$ \\
\hline & 7th edition. 2005 & REP $=\mathrm{EEP}=$ arith HEP vs. T-Bills & 1926-02 & $8.4 \%$ & $8 \%$ & $259(8.4 \%), 286(8 \%)$ \\
\hline \multicolumn{2}{|c|}{ Ross, Westerfield and Jordan (2003a) 4th edition. } & REP $=\mathrm{EEP}=$ arith HEP vs. T-Bills & $1926-01$ & $8.8 \%$ & $6-9 \%$ & $6 \%(352) ; 7 \%(380) ; 8 \%(356,367,382): 9 \%(374)$ \\
\hline \multicolumn{2}{|c|}{ Ross, Westerfield and Jordan (2003b) 6th edition. } & $\mathrm{REP}=\mathrm{EEP}=$ arith HEP vs. T-Bills & $1926-00$ & $9.1 \%$ & $6-10 \%$ & $\begin{array}{c}6 \%(517) ; 7 \%(449) ; 8 \%(445,509,520,522) ; 8.6 \% \\
(441) 9.1 \%(395,504) ; 10 \%(521)\end{array}$ \\
\hline \multirow{4}{*}{$\begin{array}{l}\text { Bodie, Kane } \\
\text { and Marcus }\end{array}$} & 2nd edition. 1993 & REP = EEP & & $6.5 \%$ & $6.5 \%$ & $549^{20}$ \\
\hline & 3rd edition. 1996 & REP $=\mathrm{EEP}=$ arith HEP vs. $\mathrm{T}-$ Bills $-1 \%$ & $1926-94$ & $7.75 \%$ & $7.75 \%$ & 535 \\
\hline & 5th edition. 2002 & $\mathrm{REP}=\mathrm{EEP}$ & & $6.5 \%$ & $6.5 \%$ & $575^{21}$ \\
\hline & 6th edition. 2003 & REP $=\mathrm{EEP}=$ arith HEP vs. T-Bills & 1926-2001 & & $5 \% ; 8 \%$ & $8 \%(426,431) ; 5 \%(415) ; 157^{22}$ \\
\hline \multirow{2}{*}{$\begin{array}{l}\text { Bodie and } \\
\text { Merton }\end{array}$} & $(2000)$ & $\mathrm{REP}=\mathrm{A} \sigma_{\mathrm{M}}^{2}$ & & & $8 \%$ & $347^{23}$ \\
\hline & and Cleeton (2009) & & & & $8 \%$ & 369 \\
\hline
\end{tabular}

18 "REP depends on (1) the average risk aversion of investors and (2) the variance of the market return. If these two don't change much, the EEP should not change either, and we may estimate REP from historical data."

19 "financial economists use [the HEP] as the best estimate to occur in the future. We will use it frequently in the text."

${ }^{20}$ They justified a REP $=$ EEP $=6.5 \%(14.5 \%-8 \%)$ by saying "Suppose the consensus forecast for the expected rate of return on the market portfolio in 1990 was about $14.5 \%$ "

${ }^{21}$ They argue that "the HEP has been closer to 9.14\%. However, after several banner years, stock analysts in mid-2000 were increasingly wary about future market performance over the short term. Although the HEP is one guide as to the EEP one might expect from the market, there is no reason that the risk premium cannot vary somewhat from period to period. Moreover, recent research suggests that in the last 50 years the HEP was considerably better than the market participants at the time were anticipating. Such a pattern could indicate that the economy performed better than initially anticipated during this period, or that the discount rate declined." 9.14\% was the arithmetic HEP using T-Bonds in the period 19261999.

22 "The instability of average excess return over the 19-year subperiods calls into question the precision of the 76-year average HEP (8.64\%) as an estimate of the EEP... There is an emerging consensus that the HEP is an unrealistic high estimate of the EEP.” 8.64\% was the arithmetic HEP vs. T-bills for 1926-2001, using CRSP data.

23 "In the CAPM, the equilibrium risk premium on the market portfolio is equal to the variance of the market portfolio ( $\left.\sigma^{2}{ }_{M}\right)$ times a weighted average of the degree of risk aversion of the holders of wealth (A). Suppose that $\sigma_{\mathrm{M}}=20 \%$ and $A=2$. Then the risk premium on the market portfolio is $8 \%$." 


\section{Exhibit 1 (continued)}

Equity premiums recommended and used in textbooks

\begin{tabular}{|c|c|c|c|c|c|c|}
\hline & Author(s) of the Textbook & Assumption & $\begin{array}{l}\text { Period for } \\
\text { HEP }\end{array}$ & $\begin{array}{l}\text { REP } \\
\text { recommended }\end{array}$ & REP used & Pages in the textbook \\
\hline \multirow{9}{*}{ Damodaran } & \begin{tabular}{|l|l} 
Damodaran on Valuation (1994) $1^{\text {st }}$ ed. \\
\end{tabular} & REP $=$ EEP $=$ geo HEP vs.T-Bonds & $1926-90$ & $5.5 \%$ & $5.5 \%$ & $22^{24}$ \\
\hline & Investment Valuation (1996), $1^{\text {st }}$ ed. & REP $=$ EEP = geo HEP vs.T-Bonds & $1926-90$ & $5.5 \%$ & $5.5 \%$ & 251 \\
\hline & Corporate Finance (1997) $1^{\text {st }}$ ed & REP $=\mathrm{EEP}=$ geo HEP vs.T-Bonds & $1926-90$ & $5.5 \%$ & $5.5 \%$ & $128^{25}$ \\
\hline & The Dark Side of Valuation (2001a) & average IEP & $1970-2000$ & $4 \%$ & $4 \%$ & $67(4 \%)^{26}$ \\
\hline & Corporate Finance (2001b) $2^{\text {nd }}$ ed & REP $=$ EEP = geo HEP vs.T-Bonds & & $5.5 \%$ & $5.5 \%$ & $237,339,425$ and 426 \\
\hline & Corporate Finance (2001c) $2^{\text {nd }}$ intl ed & $\mathrm{REP}=\mathrm{EEP}=$ geo HEP vs.T-Bonds $-0.88 \%$ & 1926-98 & $5.5 \%$ & $5.5 \%$ & $192^{27}$ \\
\hline & Investment Valuation (2002), $2^{\text {nd }}$ ed. & $\mathrm{REP}=\mathrm{EEP}=$ geo HEP vs. $\mathrm{T}$-Bonds & $1928-2000$ & $5.51 \%$ & $5.51 \%$ & $170 ; 171 ; 174$ \\
\hline & Applied Corporate Finance (2005) & REP $=\mathrm{EEP}=$ geo HEP vs. T-Bonds & $1928-03$ & $4.82 \%$ & $4-6 \%$ & $\begin{array}{c}4 \%(355) ; 4,82 \%(349,368,562) ; 5,5 \%(271, \\
389,401,481) ; 6 \% \text { (pages } 335,336) .\end{array}$ \\
\hline & Damodaran on Valuation (2006) $2^{\text {nd }}$ ed. & REP = EEP = geo HEP vs. T-Bonds & 1928-2004 & $4.84 \%$ & $4 \%$ & $41 ; 4 \%(160,173,189) ; 5 \%(341) ; 47^{28}$ \\
\hline Van Horne & $\begin{array}{l}\text { 6th edition. } 1983 \\
\text { 8th edition. } 1992\end{array}$ & $\begin{array}{l}\text { REP }=\mathrm{EEP}=\mathrm{HEP} \\
\mathrm{REP}=\mathrm{EEP}=\mathrm{HEP}\end{array}$ & & $3-7 \%$ & $\begin{array}{l}6.0 \% \\
5.0 \%\end{array}$ & $\begin{array}{l}215^{29} \\
438^{30}\end{array}$ \\
\hline
\end{tabular}

${ }^{24}$ However, on page 24 he used a REP of 6.41\% (geometric HEP 1926-1990 using T-Bills). For Germany (page 164) he used a REP of 3.3\%.

${ }^{25}$ On page 128 he used a REP of 8.41\% (arithmetic HEP 1926-1990 using T-Bills).

26 "The average implied equity-risk premium between 1970 and 2000 is approximately 4\%."

${ }^{27}$ Although the geometric HEP versus T-bonds from Ibbotson for 1926-1998 was 6.38\%, "in this book we use a premium of 5.5\% in most of the examples involving US companies." But he continued in a footnote, "we must confess that this is more for the sake of continuity with the previous version of the book and for purposes of saving a significant amount of reworking practice problems and solutions.”

${ }^{28}$ Using a dividend discount model, he concludes that "the implied premium for the US and the average implied equity risk premium has been between about $4 \%$ over the past 40 years."

${ }^{29} 6 \%=13 \%-7 \%$. He justified it saying, "Suppose, for easy illustration, that the expected risk-free rate is an average of the risk-free rates that prevailed over the ten-year period and that the expected market return is average of market returns over that period."

30 "Assume that a rate of return of about 13\% on stocks in general is expected to prevail and that a risk-free rate of $8 \%$ is expected." "The "beforehand' or ex ante market risk premium has ranged from 3 to $7 \% . "$

18 - IESE Business School-University of Navarra 


\section{Exhibit 1 (continued)}

Equity premiums recommended and used in textbooks

\begin{tabular}{|c|c|c|c|c|c|c|}
\hline \multicolumn{2}{|r|}{ Author(s) of the Textbook } & Assumption & $\begin{array}{l}\text { Period for } \\
\text { HEP }\end{array}$ & $\begin{array}{c}\text { REP } \\
\text { recommended }\end{array}$ & REP used & Pages in the textbook \\
\hline \multirow{3}{*}{$\begin{array}{l}\text { Copeland } \\
\text { and Weston }\end{array}$} & $\begin{array}{l}(1979) \\
(1988)\end{array}$ & $\begin{array}{l}\text { REP }=\text { EEP } \\
\text { REP }=\text { EEP }\end{array}$ & & & $\begin{array}{c}10 \% \\
9.83 \%, 10 \%\end{array}$ & $\begin{array}{c}321 \\
204,458,531\end{array}$ \\
\hline & Weston and Copeland (1992) & $\mathrm{REP}=\mathrm{HEP}=\mathrm{EEP}$ & & $6-8 \%$ & $5 \%, 7.5 \%$ & $\begin{array}{c}5 \%(407,944) ; 7,5 \% \\
(610)\end{array}$ \\
\hline & and Shastri (2005) & REP $=$ EEP $=$ arith. $\mathrm{HEP}$ vs. $\mathrm{T}$-Bonds & 1963-02 & $5 \%$ & $5,5 \%$ & $173^{31} ; 526$ \\
\hline \multirow{3}{*}{ Weston et al. } & $\begin{array}{l}\text { Weston \& Brigham (1982), } 6^{\text {th }} \text { ed. } \\
\text { Weston, Chung and Siu (1997) }\end{array}$ & & & $\begin{array}{l}5-6 \% \\
7.5 \%\end{array}$ & & $393^{32}$ \\
\hline & Weston, Mitchel and Mulherin (2004) & REP $=$ EEP $=$ arith.HEP vs. T-bonds & $1926-2000$ & $7.3 \%$ & $\begin{array}{c}7 \% \\
563 \%\end{array}$ & $260^{33}$ \\
\hline & Weston, Weaver and Weaver (2004), & REP $=\mathrm{EEP}=$ arith. $\mathrm{HEP}$ vs. $\mathrm{T}$-bonds & $1926-2000$ & $7.3 \%$ & $7 \%$ & 153,161 \\
\hline \multirow[b]{2}{*}{ Penman } & $(2001) 1^{\text {st }}$ ed. & "No one knows what the REP is" & & & $6 \%$ & $76,691^{34}$ \\
\hline & $(2003) 2^{\text {nd }}$ ed. & $\begin{array}{c}\text { "we do not have a sound method to estimate the } \\
\text { cost of capital" }\end{array}$ & & & $6 \%$ & $445^{35}, 443$ \\
\hline \multirow{4}{*}{$\begin{array}{l}\text { Case } \\
\text { Problems in } \\
\text { Finance }\end{array}$} & Butters, Fruhan, Mullins and Piper (1981) & $\mathrm{REP}=\mathrm{EEP}=$ geo. $\mathrm{HEP}$ vs. $\mathrm{T}-\mathrm{Bonds}+4 \%$ & 1926-74 & $9 \%$ & $9 \%$ & $150^{36}, 151$ \\
\hline & Butters, Fruhan, Mullins and Piper (1987) & REP $=$ EEP $=$ geo. $\mathrm{HEP}$ vs. $\mathrm{T}-$ Bonds $+4 \%$ & 1926-74 & $9 \%$ & $9 \%$ & 330,331 \\
\hline & Fruhan, Kester, Mason, Piper and Ruback (1992) & REP $=$ EEP $=$ arith. HEP vs.T-Bills & $1926-90$ & $8.4 \%$ & $8 \%$ & 417,418 \\
\hline & Kester, Ruback and Tufano (2005) & $\mathrm{REP}=\mathrm{EEP}=$ arith. $\mathrm{HEP}$ vs. $\mathrm{T}$-Bonds & $1926-95$ & $7.4 \%$ & $7 \%$ & 443,444 \\
\hline
\end{tabular}

${ }^{31}$ They argue that, using 1963-2002 data, "our estimate of the market risk premium would be 11.9\% (the average arithmetic return on the S\&P 500 index) minus 7\% (the average arithmetic return on intermediate-term U.S. government bonds. Thus, our estimate of the market risk premium would be roughly 5\% in nominal terms."

32 "the market risk premium can be considered relatively stable at 5 to $6 \%$ for practical application."

${ }^{33}$ They mention that the geometric HEP over T-bonds in the period 1926-2000 according to Ibbotson was 5.7\%.

34 "the market risk premium is a big guess. Research papers and textbooks estimate it in the range of 4.5\% to 9.2\%.... Compound the error in beta and the error in the risk premium and you have a considerable problem... No one knows what the market risk premium is."

35 "we really do not have a sound method to estimate the cost of capital... Estimates [of the equity premium] range, in texts and academic research, from 3.0\% to 9.2\%."

36 "In recent years, the rate of return on Treasury bills has averaged about 5 to 8\%. A reasonable estimate might be 6\%. The average annual return on the market as a whole (or an index such as the SEP 500) over the past 25 to 35 years has been in the range of 10\% to 12\%. Adjusting for higher long-term inflation might yield an estimate in the range of $14 \%$ to $16 \%$ with a midpoint of $15 \% . "$ 


\section{Exhibit 1 (continued)}

Equity premiums recommended and used in textbooks

\begin{tabular}{|c|c|c|c|c|c|}
\hline Author(s) of the Textbook & Assumption & $\begin{array}{l}\text { Period for } \\
\text { HEP }\end{array}$ & $\begin{array}{c}\text { REP } \\
\text { recommended }\end{array}$ & REP used & Pages in the textbook \\
\hline Shapiro (1992) & Defines REP correctly & & & $8 \%$ & 482 \\
\hline Shapiro (2005) & EEP $<$ HEP & & $4-6 \%$ & & $7,5 \%$ (151), $5 \%$ (160 and 187), 8\% (169), $148^{37}$ \\
\hline Jones, C. P. (1996) & REP $=$ EEP = geo. HEP vs.T-Bills & $1926-93$ & $5.3 \%$ & $7 \%$ & $154,246(7 \%)$ \\
\hline Jones, C. P. (2006) & REP $=$ EEP = geo. HEP vs.T-Bills & $1920-04$ & $6.06 \%$ & $6.06 \%$ & $160(6.06 \%) ; 255(6 ; 7 \%)$ \\
\hline Lopez and de Luna (2001) & $\mathrm{REP}=0,5$ to $0.6 \mathrm{R}_{\mathrm{F}} ; \mathrm{IEP}$ & & & $3 \%-5.5 \%$ & $\begin{array}{c}16,18,19,3.5 \%(22,85) ; 3.45 \%(43) ; 3 \%(71) ; 4 \%(145) ; 5.5 \% \\
(111)\end{array}$ \\
\hline Lopez and Garcia (2005) & $\mathrm{REP}=0.7 \mathrm{R}_{\mathrm{F}}$ & & $4.2 \%$ & $3 \%, 3.5 \%$ & $36,134,194,232$ \\
\hline Fernández (2002) & $\begin{array}{l}\text { "it is impossible to determine the premium for } \\
\text { the market as a whole" }\end{array}$ & & $4 \%$ & & \\
\hline Fernández $(2001,2004)$ & "different investors have different REPs" & & & $4 \%$ & $608,623^{38}$ \\
\hline Mascarenas (1993) & $\mathrm{REP}=\mathrm{EEP}$ & & $5-6 \%$ & & 56 \\
\hline Mascarenas (2004) & REP $=\mathrm{EEP}=$ geo. HEP vs. T-Bonds & 1928-2001 & $5.17 \%$ & $3.5 \%, 5.5 \%$ & $3.5 \%(40,165) ; 5.5 \%(40,167)$ \\
\hline Mascarenas (2005) & REP $=\mathrm{EEP}=$ geo. $\mathrm{HEP}$ vs. $\mathrm{T}$-Bonds & $1928-2001$ & $5.1 \%$ & $5.1 \%, 5.5 \%$ & $271,273,279,316(5.5 \%)$ \\
\hline Stowe et al. (2002) & REP $=$ EEP $=$ geo HEP vs.T-Bonds & $1926-00$ & $5.7 \%$ & $5.7 \%$ & $49^{39}$ \\
\hline Bruner (2004) & $\mathrm{REP}=\mathrm{EEP}=$ geo HEP vs.T-Bonds & $1926-2000$ & $6 \%$ & $6 \%$ & $265,269,294$ \\
\hline Hawawini and Viallet (2002) & $\mathrm{REP}=\mathrm{EEP}=$ geo HEP vs. $\mathrm{T}$-Bonds & 1926-99 & $6.2 \%$ & $6.2 \%$ & 328 \\
\hline Stewart (1991) & REP $=\mathrm{EEP}=$ geo. HEP vs.T-Bonds & $1925-89$ & $6 \%$ & $6 \%$ & $438^{40}, 442$ \\
\hline White (1994) & REP $=\mathrm{EEP}=$ geo. HEP vs.T-Bonds & $1926-88$ & $5.4 \%$ & $5.4 \%$ & 225 \\
\hline
\end{tabular}

37 "an expected equity risk premium of 4 to $6 \%$ appears reasonable. In contrast, the historical equity risk premium of 7\% appears to be too high for current conditions."

${ }^{38}$ He mentions that "the HEP, the EEP and the REP are different concepts" and that "different investors have different REPs."

${ }^{39}$ They also mention the "bond yield plus risk premium method." Under this approach, the cost of equity is equal to the "yield to maturity on the company's long-term debt plus a typical risk premium of 3-4\%, based on experience."

40 "Is there any fundamental reason why market risk premium should be 6\%? Not that I can figure... Don't ask. Just memorize it, and then head out to recess."

20 - IESE Business School-University of Navarra 


\section{Exhibit 1 (continued)}

Equity premiums recommended and used in textbooks

\begin{tabular}{|c|c|c|c|c|c|}
\hline Author(s) of the Textbook & Assumption & $\begin{array}{l}\text { Period for } \\
\text { HEP }\end{array}$ & $\begin{array}{c}\text { REP } \\
\text { recommended }\end{array}$ & REP used & Pages in the textbook \\
\hline Pettit (2007) & $\mathrm{REP}=\mathrm{EEP}=\mathrm{HEP}$ & $1900-2003$ & $5 \%$ & $5 \%$ & 9,16 \\
\hline Guerard and Schwartz (2007) & REP $=$ EEP $=$ arith. HEP vs. T-Bills & $1926-93$ & & $8 \%, 8.8 \%$ & $8 \%(235) ; 8.8 \%(188,276,456)$ \\
\hline Smart and Megginson (2008) & REP $=$ EEP $=$ arith. HEP vs. T-Bills & $1900-05$ & $7.4 \%$ & $6-7 \%$ & $6 \%(201,202,236) ; 7 \%(245)$ \\
\hline Butler (2000) & REP $=$ EEP $=$ arith. HEP vs. T-Bills & & & $8.5 \%$ & 618 \\
\hline Moyer, McGuigan, and Kretlow (2001) & REP $=$ EEP $=$ arith. HEP vs. T-Bills & $1926-98$ & $9.4 \%$ & $9.4 \% ; 8 \%$ & $202,427^{41}$ \\
\hline Hitchner (2006) & REP $=$ EEP = geo. HEP vs.T-Bills & $1926-99$ & $8.1 \%$ & $7 \%, 5.5 \%$ & $144,248,548$ \\
\hline Kasper L. J. (1997) & REP $=$ EEP = geo. HEP vs.T-Bills & $1954-1996$ & $7,81 \%$ & $7,81 \%$ & 143 \\
\hline Martin and Petty (2000) & REP $=$ EEP = geo. HEP vs.T-Bills & & & $8 \%$ & 97 \\
\hline Marin and Rubio (2001) & REP $=$ EEP = geo. HEP vs.T-Bills & $1963-1997$ & $6.77 \%$ & $6.77 \%$ & $209,300,304$ \\
\hline Viebig, Varmaz and Poddig (2008) & REP $=$ EEP $=$ geo HEP vs. T-Bills & $1900-2005$ & $5.5 \%$ & $4-5.5 \%$ & $7 \%(15) ; 4.82$ (18); 5,5\% (40); 4\% (235) \\
\hline Adair (2005) & $\mathrm{REP}=\mathrm{EEP}^{42}$; geo. HEP & & & $3,3 \%-8,6 \%$ & 169 (3.3\%), 175 (6\%), 179 (8.6\%) \\
\hline Evans and Bishop (2001) & $\mathrm{REP}=\mathrm{EEP}=$ arith. $\mathrm{HEP}$ vs. $\mathrm{T}$-Bonds & $1926-00$ & $7.76 \%$ & $7 \%, 7,5 \%$ & $124,135,270$ \\
\hline Rojo (2007) & $\mathrm{REP}=\mathrm{EEP}=$ arith. $\mathrm{HEP}$ & & $5 \%$ & $5-11.71 \%$ & $5 \%(122) ; 5.2 \%(130) ; 8.88 \%(132) ; 11.71 \%(153)$ \\
\hline Black, Wright and Bachman (2000) & Average HEP and surveys & & & $3.5 \%-4.8 \%$ & $3.5 \%(57) ; 4-4.8 \%(304,316)$ \\
\hline Adsera and Vinolas (1997) & & & $3-7 \%$ & $5 \%, 4 \%$ & $185,188,193,249$ \\
\hline Arzac (2005) & $\mathrm{REP}=\mathrm{IEP}$ & & $5.08 \%$ & $5.08 \%$ & Exhibit 3.4 \\
\hline Titman and Martin (2007) & commonly used in practice & & & $5 \%$ & $143^{43}$ \\
\hline
\end{tabular}

41 "If the 9.4\% market risk premium is used, then the risk-free rate must be the short-term Treasury bill rate. When the $8 \%$ market risk premium is used, then the risk-free rate must be the long-term government bond rate."

42 According to the Philadelphia Federal Reserve's Survey of Professional Forecasters

43 "The market risk premiums that are used in applications of the CAPM are simply guesses." "Historical data suggest that the equity risk premium for the market portfolio has averaged $6 \%$ to $8 \%$ a year over the past 75 years. However, there is good reason to believe that looking forward the equity risk premium will not be this high. Indeed, current equity risk premium forecasts can be as low as 3\%. For the examples of this book we will use an equity risk premium of 5\%, which is commonly used in practice." 


\section{Exhibit 1 (continued)}

Equity premiums recommended and used in textbooks

\begin{tabular}{|c|c|c|c|c|c|}
\hline Author(s) of the Textbook & Assumption & $\begin{array}{l}\text { Period for } \\
\text { HEP }\end{array}$ & $\begin{array}{c}\text { REP } \\
\text { recommended }\end{array}$ & REP used & Pages in the textbook \\
\hline Kim and Kim (2006) & REP $=\mathrm{EEP}$ & & & $10 \%$ & 402,420 \\
\hline Lumby and Jones (2003) & $\mathrm{REP}=\mathrm{EEP}$ & & & $5-7 \%$ & 264 (6\%), 267 (7\%), 648 (5\%) \\
\hline Goetzmann and lbbotson (2006) & $\mathrm{REP}=\mathrm{EEP}$ & & & $6.2 \%$ & $7^{44}, 8,269$ \\
\hline Benninga and Sarig (1997) & $\mathrm{REP}=\mathrm{EEP}$ & & & $8 \%$ & $242,259,266,298,365,367$ \\
\hline Estrada (2006) & REP $=$ EEP. Defines REP correctly & & $5.5 \%$ & $5.5 \%$ & $75^{45}, 76,176$ \\
\hline Palepu and Healy (2007) & $\mathrm{REP}=\mathrm{EEP}=\mathrm{HEP}$ & & & $4,9 \%$ & $331,333^{46}, 334$ \\
\hline Feldman (2005) & REP $=\mathrm{EEP}=\mathrm{HEP}$ & $1926-2001$ & & $7.4 \%$ & 70 \\
\hline Sanjurjo and Reinoso (2003) & REP $=$ EEP $=$ HEP & & $5-8 \%$ & $5 \%, 5.5 \%$ & $69,240,311,328,387$ \\
\hline Tham and Vélez-Pareja (2004) & REP $=\mathrm{EEP}=\mathrm{HEP}$ & & & $6-7.5 \%$ & 314,319 \\
\hline Ryan (2006) & $\mathrm{REP}=\mathrm{EEP}=\mathrm{HEP}$ & $1900-2001$ & & $3.5 \%$ & $102,314,319$ \\
\hline Pratt (2002) & $\mathrm{REP}=\mathrm{EEP}=\mathrm{HEP}$ & & & $7.4 \%, 8 \%$ & 68,74 \\
\hline Antill and Lee (2008) & $\mathrm{REP}=\mathrm{EEP}=\mathrm{HEP}$ & $1900-2005$ & $3-4 \%$ & $3.5-4 \%$ & $34,4 \%(202,217,288) ; 3.5 \%(45,49,51)$ \\
\hline English (2001) & REP $=5 \%<\mathrm{HEP}$ & & & $5 \%$ & 228,305 \\
\hline Pereiro (2002) & $\mathrm{REP}=\mathrm{EEP}<\mathrm{HEP}$ & & $4 \%$ & $4 \%$ & 120 \\
\hline Siegel (2002) & $\mathrm{REP}=\mathrm{EEP}<\mathrm{HEP}$ & & $2-3 \%$ & & $124^{47}$. \\
\hline Berk, DeMarzo and Harford (2008) & $\mathrm{EEP}<\mathrm{HEP}$ & & & $5 \%$ & 48 \\
\hline
\end{tabular}

44 "The Equity Risk Premium is the expected return of the stock market minus the expected return of a riskless bond." "It figures into the cost of equity capital." "From the valuation viewpoint, it figures into the discount rate that is used in calculations of present value."

${ }^{45}$ Estrada defines correctly the REP: "the additional compensation required by investors for investing in risky assets as opposed to investing in risk-free assets."

46 "It is prudent to use a range of REP estimates in computing a firm's cost of capital."

${ }^{47}$ He concluded that "the future equity premium is likely to be in the range of 2 to $3 \%$, about one-half the level that has prevailed over the past 20 years."

48 "Some researchers believe that the future expected returns for the market are likely to be even lower than these historical numbers, in a range of 3\% to 5\% over Treasury bills."

22 - IESE Business School-University of Navarra 


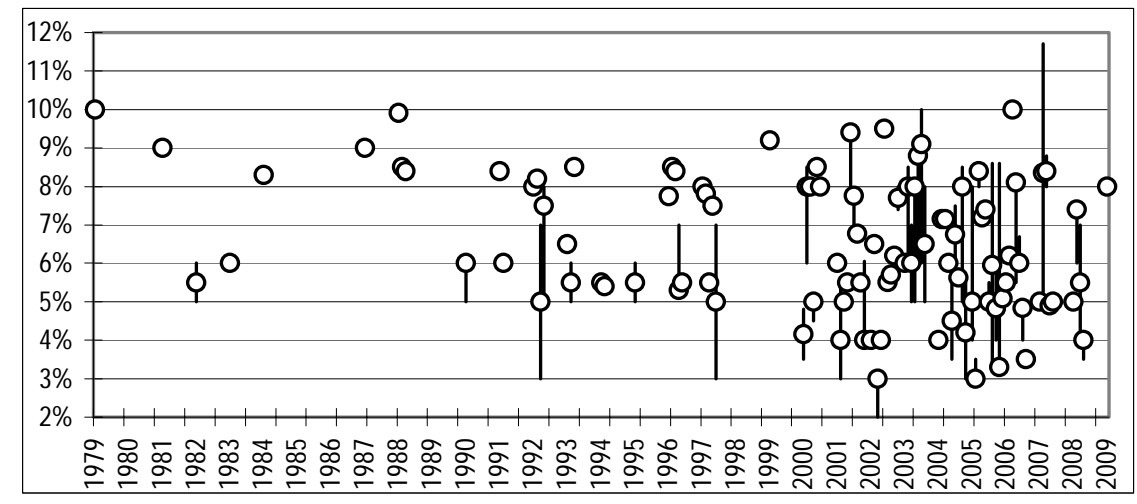

Young, S.D. and S. F. O'Byrne (2000), EVA and Value-Based Management: A Practical Guide to Implementation, $1^{\text {st }}$ edition, McGraw-Hill. Grant, J. L. (2002), Foundations of Economic Value Added, 2nd edition, Wiley.

Martin Marin, J. L. and A. Trujillo (2000), Manual de valoracion de empresas, Ariel.

Mascarenas, J. (1996), Manual de Fusiones y Adquisiciones de Empresas, 2nd edition, Madrid: McGraw Hill.

Amor, B. (2005), Valoración de Empresas: El EBO en la valoración de acciones, Universidad de León.

Fabozzi, F.J. and J. L. Grant (2000),Value-Based Metrics: Foundations and Practice, $1^{\text {st }}$ edition, Wiley.

\begin{tabular}{|c|c|c|c|c|c|}
\hline Author(s) of the Textbook & Assumption & $\begin{array}{c}\text { Period for } \\
\text { HEP }\end{array}$ & $\begin{array}{c}\text { REP } \\
\text { recommended }\end{array}$ & REP used & Pages in the textbook \\
\hline Young and O'Byrne (2000) & "widely used" & & $5 \%$ & $5 \%$ & $166,168,174$ \\
\hline Martin and Trujillo (2000) & $\mathrm{REP}=\mathrm{EEP}$ & & & $3 \%, 4 \%$ & $146,148,159,160,166(4 \%)$ \\
\hline Mascarenas (1996) & $\mathrm{REP}=\mathrm{EEP}=\mathrm{HEP}$ & & $5-6 \%$ & $5 \%$ & 104 \\
\hline Amor (2005) & $\mathrm{REP}=\mathrm{EEP}$ & & $3-4 \%$ & & 94 \\
\hline Fabozzi and Grant (2000) & REP $=\mathrm{EEP}=$ geo HEP vs. - -Bonds & 1926-93 & $5-6 \%$ & $5 \%$ & $82,83,154$ \\
\hline
\end{tabular}

